\title{
THE VUCA ERA CREATES COVID-19 PANDEMIC IN INDONESIA BEING COMPLICATED
}

\author{
Ricardi S Adnan, Fadlan Khaerul Anam, and Radhiatmoko Radhiatmoko \\ Department Sociology, Faculty of Social and Political Sciences, Universitas Indonesia \\ Email : adnanricardi@gmail.com
}

\begin{abstract}
This article aims to analyze the confusion of information, uncertainty in the situation, and human puzzlement have overshadowed the actions of Indonesian citizens throughout 2020 until the end of January 2021 in line with the pandemic outbreak which have not yet ended and still cannot be predicted when it will end. Volatility, uncertainty, problems of complexity and ambiguity of the choices are conditions that have been described by the VUCA concept. Covid-19, which has infected more than one million people in the country, has caused a lot of excitement in various domains: economic, political, social, cultural, and various other aspects of life. By conducting a literature review from March 2020 to January 2021 and analyzing secondary data from Twitter and distributing short questionnaires through Google Form on August 2020, as 969 respondents in Java, Bali, Sumatera, Kalimantan, Sulawesi, Nusa Tenggara dan Papua Islands the authors found that the VUCA era facilitates various complexities in dealing with the Covid-19 pandemic. The clumsy policies create uncertainty way in the process of social transformation towards society who cares about health protocols. Some of the solutions offered by Bennet and Lemoine (2014) or Aura Codreanu (2016) are still insufficient to manage the changes that occur towards a better life. This article contributes ideas related to social action about new social care, togetherness, and responsibility for realizing a new normal life.
\end{abstract}

Keyword: VUCA; Covid-19; health protocol; social transformation; Large-Scale Social Restrictions

\section{ERA VUCA MENCIPTAKAN KONDISI PANDEMI COVID-19 DI INDONESIA SEMAKIN KOMPLEKS}

\begin{abstract}
ABSTRAK. Artikel ini bertujuan menganalisis kesimpangsiuran informasi, ketidakpastian situasi, serta kegalauan manusia yang membayangi tindakan warga Indonesia sepanjang tahun 2020 hingga akhir Januari 2021 seiring dengan pandemi yang belum berakhir dan tidak bisa diprediksi kapan akan selesai. Kerentanan, ketidakpastian, kompleksitas masalah dan ambiguitas dari berbagai pilihan-pilihan merupakan kondisi yang dijelaskan oleh konsep VUCA. Covid-19 yang telah menjangkiti lebih dari satu juta jiwa di tanah air menimbulkan banyak kehebohan di dalam berbagai ranah; ekonomi, politik, sosial, budaya dan berbagai aspek kehidupan lainnya. Melalui kajian kepustakaan sejak Maret 2020 hingga Agustus 2020 dan dengan melakukan analisis data sekunder dari Tweeter serta penyebaran kuesioner ringkas melalu google form kepada 969 responden di Pulau Jawa, Bali, Sumatera, Kalimantan, Nusa Tenggara, Sulawesi dan Papua penulis menemukan bahwa era VUCA memfasilitasi berbagai kerumitan dalam menghadapi Covid-19. Kebijakan kikuk dari pemerintah menciptakan jalan ketidakpastian dalam proses transformasi sosial menuju masyarakat yang peduli terhadap protokol kesehatan. Beberapa argumentasi yang ditawarkan oleh Bennet dan Lemoine (2014) atau Aura Codreanu (2016) masih belum cukup mampu mengelola perubahan yang terjadi menuju kehidupan yang lebih baik. Artikel ini memberikan sumbangsih gagasan terkait aksi sosial tentang kepedulian tatanan sosial baru, kebersamaan, dan tanggung jawab untuk mewujudkan kehidupan normal baru.
\end{abstract}

Kata Kunci: VUCA; Covid-19; protokol kesehatan; transformasi sosial; Pembatasan Sosial Berskala Besar

\section{INTRODUCTION}

The big celebration at the end of the 2019 night was marked by various activities that were not much different from the same events as the previous years. Not long after the uproar, optimism began to fade after the plague that hit China quickly spread to several neighboring countries in Asia and European regions within a few weeks then infected 198 countries recorded on March 25 and continued to grow to 213 countries on June 20, 2020. Not only in quantity, but COVID-19 has also had a major impact on life (Sismondo, 2020; Paniati, 2020) and the dramatic changes for the Van Dijk civilization (2020) which can be seen from the many political, economic, sports, educational and other socio-cultural activities that have been postponed or even canceled.

Globalizing COVID-19 marked that globalization not only brings science, technology, (Castells, 2010) culture (Fukuyama, 1999) and politics (Ohmae, 1995) but also disease outbreaks Coronavirus causes abnormalities in many sectors of activity in almost all countries in the world. While the spreading of outbreak in global is going to be unpredictable, the number of Indonesian people who contracted Covid-19 on September 29, 2020, has exceeded 270,000. Apart from the public, there are many state and government officials who have tested positive: initiated by the Minister of Transportation on March 14, 2020, and Mayor of Bogor, after 
returning from abroad. Then, many of senior officers of governments institutions, provinces, counties, and villages were infected even some of them has passed away.

Although the number of infected peoples by COVID-19 in Indonesia is rising, policy makers in first period of outbreak make uncoordinated responds. On March 9, 2020, the President appointed the Secretary of the Directorate General of Disease Prevention and Control of the Ministry of Health (echelon 2) as the government spokesman regarding Covid-19 in Indonesia replacing the role of the Minister of Health and other state officials who often made confusing statements. Furthermore, on March 13 a Task Force for handling Covid-19 was formed. The government also make hesitant attitude in implementing the health protocol that was urged by WHO at the end of January. In contrast, nongovernmental institutions try to take responsibility in facing the outbreak earlier. On March 13-14, namely the Universitas Indonesia followed by Universitas Gadjah Mada, Institute Pertanian Bogor, Universitas Airlangga and other universities to announce the Long-Distance Study to replace activities in class. On March 15, the Ministry of Education and Culture began giving instructions to schools and colleges to carry out Long Distance Study which was responded to by closing schools and returning students from Islamic Boarding Schools (Pesantren). The Covid-19 Response Task Force on March 17 issued a health protocol with three main concepts: washing hands, wearing a mask, and maintaining social distance.

Unpredictability of global outbreak, uncoordinated strategic communication by policy makers and experimentation of action by non-governmental institutions became three key aspects of COVID-19 situation in Indonesia that need to further study. This article tries to reveal how pandemic leads social transformation that constituted by Volatility (vulnerability),Uncertainty(uncertainty), Complexity (complexity) and Ambiguity (ambiguity) shortened as VUCA.

VUCA concept was first introduced by the United States Military (US) in the late 1980s after the end of the Cold War. (Bennett, Nathan \& G. James Lemoine, 2014; Codreanu, 2016: van Tulder, Rob. Barbara Jankowska and Alain Verbeke, 2020). Threat challenges arise from various directions and with various scenarios that are sometimes unpredictable mathematically, but their emergence and its devastating effects must be overcome. This means that at any time the US military must be able to face increasing challenges with asymmetrical opponents such as non-state militias and others that are organized "fluidly", sometimes the enemy it faces is "virtual". (Casey, 2018). This important topic in military academies in the US is relevant to the shocks in the civilization of human life that have undergone great disruption (Fukuyama, 1999) and the digital era which is the backbone of daily activities (Castel, 2010). In fact, Dominique Boullier (2017) argues that society is formed by big data that spreads through social media. Regarding, this pandemic situation there were good examples about VUCA as below:

\section{METHOD}

To map and analyze VUCA during the Covid-19 tantrum, researchers conducted a study of mixed methods from various secondary data published by the National Disaster Management Agency (BNPB), the Task Force for the Acceleration of Handling Covid-19 / Covid-19 Handling Task Force, several regulations contained in many reports in the mass media as well as big data spread in social media and, also short quantitative research.

Data from social media was collected using workbenchdata.com. The website is used by data journalists to track public opinion on social media. In this study, the researcher decided to collect twitter data. Workbench as a third party facilitates access to Twitter by linking the researchers' twitter to request permission on Twitter to collect data. Twitter is more open than Facebook for several reasons which brings people through hashtags related to various issues and allows people to engage in broader debate. Twitter also makes it easier for its users to follow each other without having to add to their friends list. Twitter is also today the only social media that offers broad access to big data on conversations on Twitter rather than Facebook and Instagram.

Technically, data is collected through the keyword corona OR korona lang: in. this means that all tweets that mention these words in Indonesian will be collected. The workbench has a limitation in that the maximum data collected is 100 thousand rows. To reach the maximum limit, the researcher arranged data collection every 15 minutes. Data were collected from March 1-13. This timeframe is important because on March 2 , the Indonesian government announced the first case of Covid-19. This means that this timeframe is the right time to track the earliest information circulating on Twitter about Covid-19 in Indonesia. The data collected was processed through manually categorizing the tweets into several categories. 


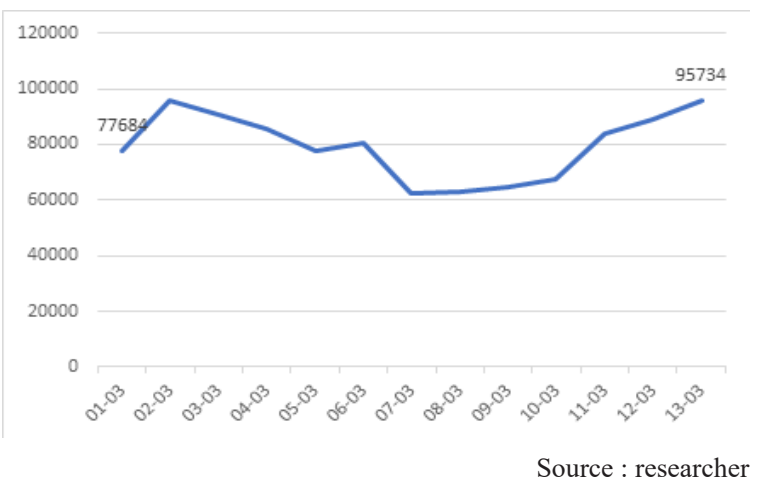

Figure1. Twitter Data Trend

A quick quantitative survey was carried out by convenience sample technic using Google form and distributed to the WhatsApp Group network from September 22 to September 24, which is spread almost all over Indonesia which includes, Greater Jakarta (Jabodetabek), Surabaya, Bandung, Padang, Medan, Makassar, Bali, Aceh, Pontianak, Palangkaraya, Timika and Wakatobi with an age range of $15-77$ years old with a response of 969 people. To measure a person's level of concern about the dangers of the Covid-19 pandemic, a question is given with a Likert scale size which is modified into 7 sequences of ratio scale: from " 1 strongly disagrees to "7 strongly agrees. The next two statements are submitted to the respondent with a recall memory of the respondent's feelings 3-4 months ago and 5-6 months ago. The analysis shown is using a comparison of the mean score.

\section{RESULTS AND DISCUSSION}

Besides influencing human health until death, disease outbreaks in the millennial era have had a huge impact on various aspects of life. With the world connected in a large global network (Ohmae, 1990) the events that develop in this country cannot be separated from events in others, especially information technology with increasingly influential social media (Castel, 2010) boosting various uncertainties amid hesitation to carry out activities in the next year. Clara González-Sanguinoa, et al. (2020) concluded in their study that the situation of alarm generated by Covid- 19 has turned into a crisis with authentic consequences throughout the world. It was caused by failing match with health protocol. As happens with many of Indonesian particularly the young people behave like their reference people (Abdul Aziz, 2020) particularly American who do not obey with the health protocol. In several big cities such as Jakarta and its surroundings, the very high number of people who died related to Covid-19 has resulted in burial grounds becoming critical. So that the burial solution had appeared that could be implemented in a certain public cemetery by only providing a special area or carrying out an overlapping burial system.

They were several unique situations regarding to stop Corona pandemic. As happened in the spread of HIV AID, (Ariadne, 2017) young people who are potentially affected have been socialized not to avoid free sex and use of needles without permission, but the danger of pandemic did not concern them. Despite the direction of social transformation because of Covid-19 towards a society that cares about health protocols, the dynamics of transmissions are undergoing a very complicated situations in the process of social transformation from life before the emergence of the pandemic.

\section{Volatility}

The disease carried by Covid-19 does not consider social status, religious traditions, fitness level or a person's age. The statement by Tom Hanks and his wife that they had infected by Covid-19 on March 13, 2020, in Australia while shooting a film has taken the world by storm. Then, several world leaders are also positive namely Bolivian President Jeanine Anez on July 9. British Prime Minister Boris Johnson on April 5, President of Brazil, Jail Bolsonaro on July 7, Prince Charles on March 25, 2020, Advisor to the Iranian Minister of Foreign Affairs who later died on March 5, 2020, as well as the President of Honduras on Tuesday 23 June. Amazingly, after being criticized by many countries the President of the USA officially withdrew from the WHO on Monday, July 6, 2020, and stated that America was stopping its routine assistance to the organization under the United Nations. Trump reasoned that the WHO had failed in dealing with the pandemic and accused the UN health agency of being a "puppet" of China.

Volatility affects not only individual health and safety, but also employment status and livelihoods. As stated by the Coordinating Minister for the Economy, the number of layoffs (PHK) which increased the unemployment rate, and the poverty rate experienced a drastic increase in mid-August. Data regarding layoffs has exceeded the figure of 2.1 million workers, increasing the poverty rate from 9.41 to 9.78 percent in just 6 months after the pandemic broke out. Even 34,100 migrant workers have returned to their homeland. If added to the informal sector workers who lost their jobs, there could be more than 3.5 million people (Kompas. com - 10/08/2020, 06:54 WIB). Such data, of course, brings up the next following problem: social problems are on the rise. 


\section{Uncertainty}

Various things related to Covid-19 and how to deal with it are full of uncertainty. The origin of the germs that spread throughout the world, bringing about great changes in human life, cannot be ascertained for its origin and the destination as well. Various theories with their rationalization emerged are believed by various groups of people: the initial speculation believed by the world community was related to the source of the virus which was a mutant of microorganisms derived from wild animals consumed by the inhabitants of Wuhan; can be from bats and can be from pangolin. Then a conspiracy theory emerged arguing that the city of Wuhan, which has sophisticated biological laboratories, is developing biological weapons, however, due to negligence, the developed virus escapes out. Then a counter conspiracy theory emerged which stated that it was the American soldiers who attended the military Olympics in Wuhan City in November 2019 who deliberately released the virus to hamper China's extraordinary economic and political growth. Speculation continues to grow until countries in the world no longer need to worry about where the virus originated.

On January 30, 2020, WHO declared the highest level of global emergency for the Covid-19 outbreak. At that time there were only 82 cases of this virus outside China, with 10 cases occurring in Europe and no cases in Latin America or Africa. Since then, the WHO Director has appeared on various television media and through social media networks to provide explanations about the dangers of Covid-19 and convey health protocols. Countries around the world would immediately pay attention to WHO's call in their own ways in overcoming the pandemic. However, several countries have refused the idea, such as in the United States and Germany. Indonesia chose the Large-Scale Social Restrictions (PSBB) policy instead of the term Regional Quarantine by implementing the health protocols compiled by the Covid-19 Handling Task Force. However, this term was renamed more than ten times with several reasons as well as consequences.

The issue of uncertainty started with the diminishing public credibility of WHO and then spread to various matters. In the first four months, the pandemic, which became a reference for various countries in the world, helped increase public confidence that the outbreak could be resolved immediately. However, towards the end of April, various speculations emerged against world health institutions, thereby dispelling confidence, especially rumors that $\mathrm{WHO}$ officials were running the vaccine business and were involved in the emergence and spread of Covid-19. Speculation regarding the emergence of this virus also has many variants; gene mutases from animals consumed in China such as bats, a biological weapon developed by China, by the United States and Israel.

Confusion of information has arrived at the most crucial stage, namely, how to treat those affected by diseases and drugs to prevent them. The President of Brazil and US President stated on April 18 that Hydroxy Chloroquine was taken to prevent Corona. High-ranking officials in Indonesia were also promoting this malaria drug as a Corona vaccine. Several ideas emerged how to prevent Corona disease such as the use of eucalyptus oil and others that were spread by social media. Information confusion is contributed significantly by social media which has grown beyond anyone's control. As the role of digital technology, which is the container for human life, is currently known as an information explosion (Dwivedi, et.al, 2018; Umeozor, 2019).

DKI Jakarta is the first province to respond to the Covid-19 pandemic in Indonesia. However, what was done in early March 2020, was considered by some people as an attempt by him to find a political stage for the 2024 Presidential Election and was labeled too over-acting on this virus, which is believed to have not yet been a case in Indonesia. Therefore, at the end of March, there were still many people who followed the carelessness of state officials, both Ministers and members of parliament, by making jokes that belittled the plague. In general, public perceptions are divided in two; some believed the governor's statement, and some believed the statement rejecting Covid-19 had entered the country.

What people share in their mind in first week of March 2020 were heavy of the unconsciousness of the danger of Corona Virus.

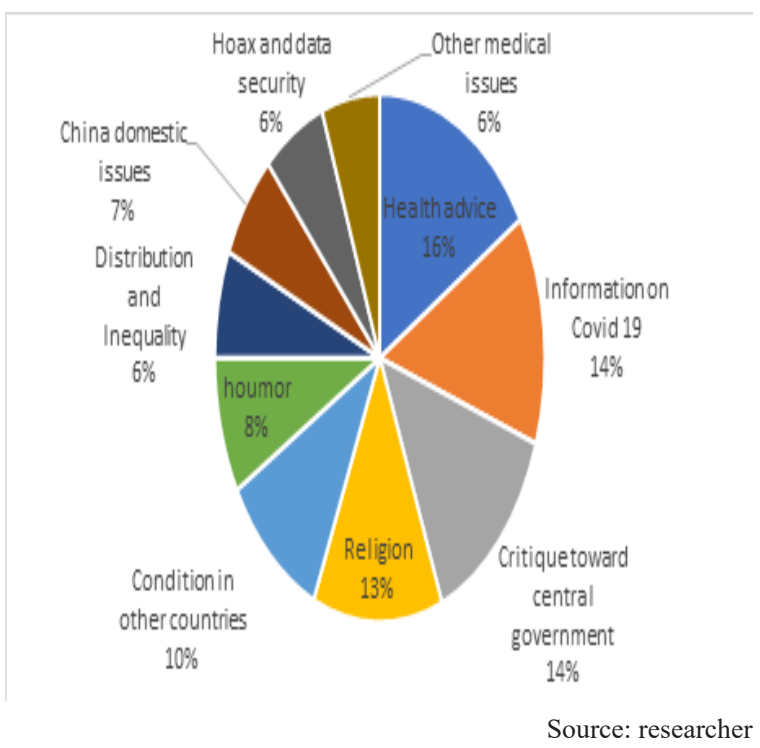

Figure 2. Number of Tweets by Category 
The highest amount of content of the 300 most shared tweets is related with health advice. Although the largest number, this number is almost the same as content regarding Covid-19 information, criticism of the central government, religion, and conditions in other countries. This indicates that the information circulating among Twitter users in the early of this case in Indonesia was related to these 5 issues. Meanwhile, other issues that appear in the "tweet" are related to humor, poor drug distribution, issues related to China, hoax issues and data security, as well as comparisons with other medical issues.

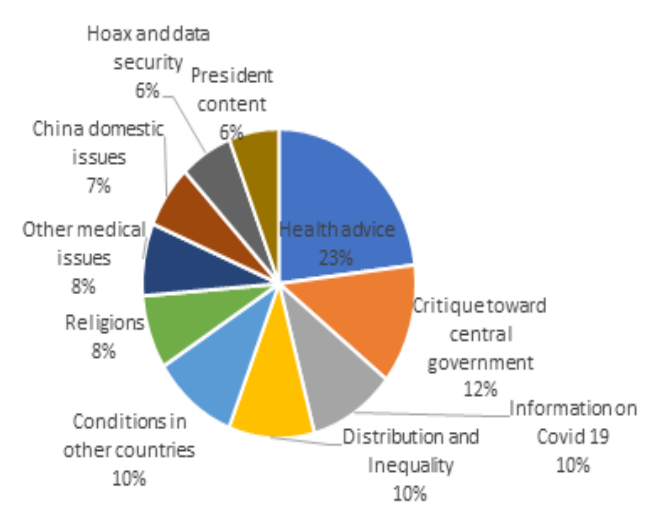

Source: researcher

Figure 3. Most shared Tweet by Category

Health protocol such as tips on avoiding Covid-19, using hand sanitizer and masks are mostly shared on Twitter. These 2 times more shared than content that criticizes policies and statements from the central government in response to it. And 3 other issues such as content containing updates on this virus case, content on PPE distribution, and other countries policy responses are the same. Whereas other types of content are much less shared. Contents of the president's Twitter account also on the top 10, even though the lowest. This indicates the government's attitudes and statements become the center.
Based on the area graph above, content that criticizes central government policies has preceded other types of content and was most shared at the earliest before the announcement of Covid-19. This indicates public pressure and concern over the government's attitude influenced before the case is announced. On the following day, increased health advice content and its information were widely shared. One day after the announcement of the first case in Indonesia, Twitter had a lot of content regarding the difficulty of access to health services and PPE, followed by various speculations about the condition of Covid-19 in China and the Indonesian government's ambiguous attitude towards Chinese tourists and conditions in other countries, and the spread of personal identities of the patients. On the following day, Twitter was enlivened with content comparing other health issues such as dengue fever, influenza, smokers' health, and others. On March 7, the response from religious leaders became a concern. However, Content from the new president's Twitter account was widely shared on March 9, 2020.

In the second week of June, the ban on entry and exit from the region was abolished in the form of a government policy on easing the PSBB, which can be interpreted that the health protocol applied at the beginning of the Eid homecoming season in the second week of May to the first week of June is something that is excessive. As a result, the level of public awareness of health protocols has decreased

On April 9, the Ministry of Transportation issued Regulation of the Minister of Transportation Number 18 of 2020 concerning Transportation Control in the Context of Preventing the Spread of Corona Virus Disease 2019 which was signed by the Minister of Transportation Ad Interim. However, in its implication, it creates confusion in the community: whether online motorcycle taxis can carry passengers as they have

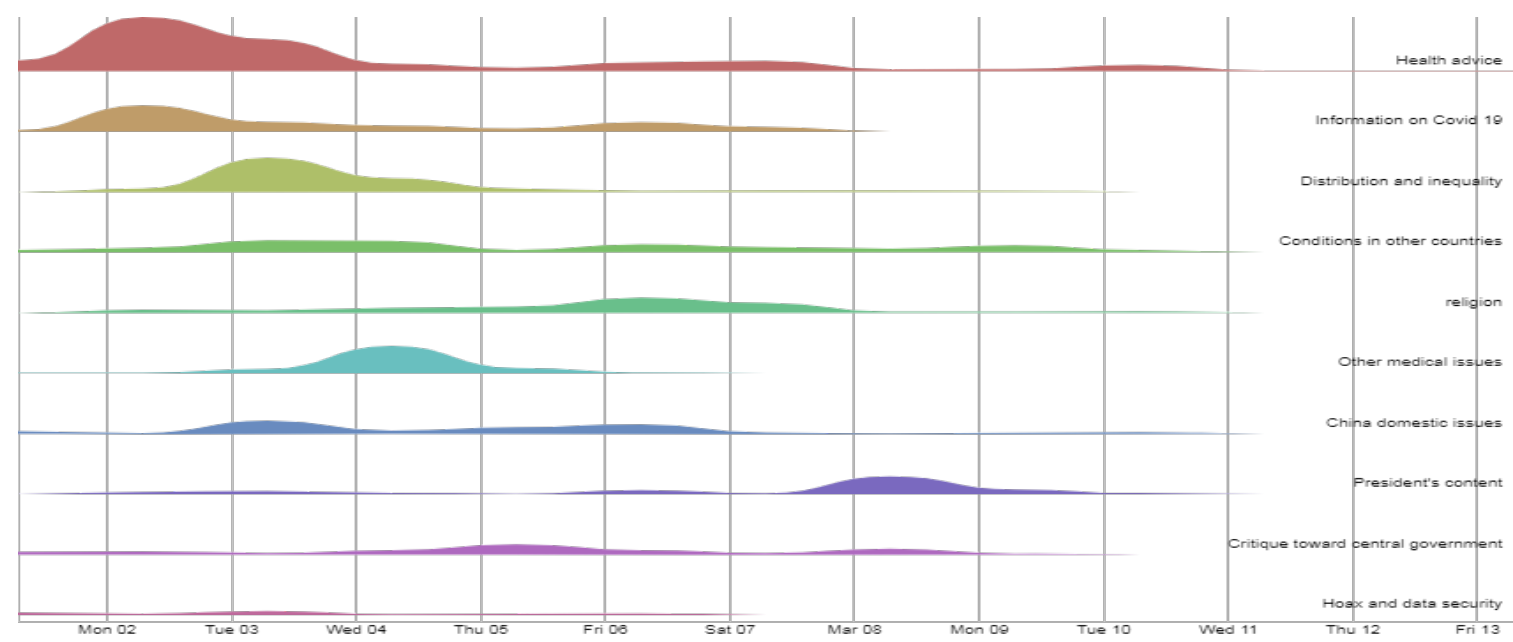

Figure 4. Issues related to Covid-19 on Twitter March 2020 
been. This regulation is followed by the DKI Governor Regulation No.33/2020 which was enforced on April 10,2020 , by allowing two-wheeled vehicles to only carry passengers if the driver and passenger have the same home address. This confuses about 1 million online motorcycle taxi drivers in Greater Jakarta (Jabodetabek) who operate in DKI and around that many workers or residents who previously used to use online motorcycle taxi services in Jakarta.

A few days later, namely on April 14, 2020, the government through the Ministry of Transportation (Kemenhub) allowed online motorcycle taxis to return to transport passengers in areas that apply the PSBB. The Ministry of Transportation's policy is seen to be contrary to the Ministry of Health's policy of Article 15 of Minister of Health Regulation Number 9 of 2020 concerning PSBB Guidelines for the Acceleration of Handling COVID-19 which states that online motorcycle taxis can only operate to transport goods, not people. This is intended so that all parties, especially online motorcycle taxi drivers, to be able to carry passengers, clearly violates the essence of physical distancing.

The Ministry of Transportation also prohibits homecoming activities from 24 April to 31 May 2020. This rule applies to all land transportation modes with strict sanctions for violators in the form of being forced to turn back a vehicle that tries to get out of the PSBB area like Jabodetabek or criminal sanctions and a fine of IDR 100 million. But it did not last long, the regulation was then changed, and all modes of transportation could resume operations on 7 May 2020, but with limited criteria. Likewise, the ban on going home (going in and out of an area) ended on June 7 with the issuance of Circular Letter (SE) No.7 of 2020 by the Task Force for the Acceleration of Handling Covid-19 replacing Circular Letter No. 5.

\section{Complexity}

Efforts to prevent and handle a pandemic are faced with a variety of strategic and practical interests from various elements in the country: development programs from the government, business interests of entrepreneurs, political interests from political parties and their leaders; weak coordination between institutions; and more importantly, the level of public awareness and compliance with health protocols that are less disciplined. Indonesia's economic growth, which experienced a contraction of $2.972 \%$ compared to the first quarter (y-o-y) of 2019 with the image that it will worsen, has prompted the President of the Republic of Indonesia on June 20, 2020 to disband the Task Force for the Acceleration of Handling Covid-19 and form a Task Force for
Handling Covid-19 which is under the Coordinating Minister for Economic Affairs through Presidential Regulation Number 82 of 2020 concerning the Committee for Handling Covid-19 and National Economic Recovery. The rationality of handling the pandemic under the Coordinating Minister for the Economy looks right considering that in the second quarter the Indonesian economy experienced the worst contraction of 5.93\% (y-o-y). Therefore, although on several occasions the President said that "public health" is the priority, in practice in the field it appears that economic-business activities are the main activities, and health protocols play a supporting role in these activities. The increase in the number of unemployed by 3.7 million people as well as the increase in the percentage of people below the poverty line has become a frightening ghost, which if not stopped could get bigger and have more dire impacts. Furthermore, great attention to the economy is not only for protecting people's lives but a reflection of the interests of elites in government and political parties that own businesses as well as buzzers who are clienteles of these figures.

Concern about the Covid-19 pandemic will transform into a recession and continue in the economic crisis had caused panic to high-ranking officials was reflected by The Coordinating Minister for Economic Affairs responded to the local policy. Such as, after the Governor of DKI announced that he would "pull the emergency brake" on September 10. The concerns of the figures were met with the panic of elite groups through social media that condemned the policy, which resulted in a negative response from the market and a fall in the Composite Stock Price Index (IHSG). The fall in the IHSG signals an imminent economic recession. After one day of experiencing a decline in the JCI, on Monday the index increased which raised questions. Is it true that the market is contracted due to the implementation of the Jakarta PSBB? An economic condition that is very sensitive to public discourse is said by Robert J. Shiller (2019) as narrative economic. Furthermore, the statement on the withdrawal of the emergency brake, because of the increase in Covid-19 cases in the country's capital, was responded loudly on social media which indicated the remnants of political battles in the 2017 DKI Jakarta Governor Election and the 2019 Presidential Election. Efforts to accelerate the handling of Covid-19 is often colored by emotional lingering in the political arena. The Head of BNPB attempted to confirm during the formulation of this PSBB policy that the Governor did not mention the word "PSBB Total" for DKI Jakarta. It turned out that after an investigation, the term "PSBB Total" 
appeared in the mass media. Recently, it has often been inadequate in informing something because of a time competition with social media. This weakness makes the media often get stuck using terms that are not necessarily precise and accurate as real facts. On the other hand, the issue that has already gone viral on social media is exacerbated by the relatively low level of digital literacy in society.

Another very basic problem is the state's unpreparedness in the institution for handling it. Weak information and coordination between institutions has caused more than 100 doctors and medical personnel to die as the result of a shortage of personal protective equipment and equipment. The procurement of medical equipment which must be carried out quickly is hampered by various bureaucratic procedures that are not deftly completed by the parties concerned. Likewise, data and information that often differ between institutions has resulted in inaction in handling. Spiritually, medical personnel have conveyed that fatigue in dealing with the pandemic since the first two months of this incident exploded on the grounds that they had long left their families fighting for their patients' health. However, the appreciation of the incentives for medical personnel promised by the government only three months later can be disbursed and that too is in the process of being paid in installments.

People also feel tired and tired since the PSBB was relaxed in June. Tourist spots are raided to vent boredom at home and for recreation. Since this time, the behavior of public compliance with health protocols has begun to loosen along with loosening of control and law enforcement from the authorities towards offenders. It cannot be denied that the decline in the level of public compliance is due to confusion over various policies from the government, many of which are difficult to understand as well as the behavior of local elites who do not provide good examples, such as carrying out their children's wedding parties by holding Dangdut music concerts or political figures who invite the masses to join them actively involved in the Pilkada (region election).

During the current pandemic, hoaxes also spread, especially those that occurred on social media. Government policies tend to limit information reporting on the threat of Covid-19, both at home and abroad. Social media has in many ways replaced the role of mass media, but in real life it is an important means of creating a variety of uproar. Besides exacerbating differences in political views related to a policy, social media has also become a means of promotion for businesspeople to take advantage of the pandemic situation for economic interests.
Some viruses that interfere with health protocols are the issue that hospitals can easily convict patients who die from being infected due to Covid-19. The hospital is suspected of seeking profit / getting assistance from the government of 200 million rupiah for treating Covid-19 patients and 350 million rupiah if the patient dies. Public distrust increases when a family member dies while his family believes that the person concerned is not affected by Covid-19 forcibly picking up the body and wants to be buried normally in accordance with the traditions of the community concerned in many places such as in Manado, Makassar, Surabaya, Madura, Batam, Bekasi, and Lombok. Family-owned data is flowed up via social media to confront hospital statements. This fact proves that distrust in Indonesian society is still high as the results of research by Fahmi et.al (2019) regarding the level of individual and community trust in health.

Efforts to prevent the spread and handling of this pandemic were subsequently faced with the issuance of a dilemmatic policy, namely being able to prohibit the implementation of 3,000 local and regional election (pilkades) but still running simultaneous regional elections in December 2020. Although many have been criticized by some parties, the political decisions of the government show that there have been many violations of health protocols that have occurred during the registration period and at the beginning of the campaign for regional head candidates.

\section{Ambiguity}

Efforts to deal with the spread of Covid-19 are faced with several contrasting dichotomies: prioritizing health or maintaining the sustainability of economic activity; consistent with health protocol or prioritizing politics which has become the breath of development; prioritizing the interests of citizens in a region or national interests. Lockdown countries such as China, South Korea, New Zealand, and Italy can quickly reduce the number of the spread of Covid-19. However, this successful project was not possible for the Indonesian government. Due to the limited state budget, it is impossible to guarantee the availability of food and other people's needs during the lockdown period. The policies taken by the provincial government were not a few that were not considered by the central government. Likewise, the policies taken by the regional government are often considered bad by the provincial and central governments.

The Jakarta Governor's policy in early April 2020 which prohibited two-wheeled motorized vehicles from attracting passengers, limiting office working hours, closing shops and entertainment venues had a 
huge economic impact so that many people shouted to be reopened immediately. The reduction in the operational capacity of the Trans Jakarta and the MRT has created full passengers and then resulted in failing to implement one of the main principles of the health protocol "maintaining distance", and vice versa. PT KAI's policy of reducing operating hours and the number of commuter line carriages has had the effect of long queues which in fact caused the productivity of employees at work to decrease drastically. Provincial governments were also facing the same dilemma with the increasing number of positive cases infected with this deadly virus through enforcing strict discipline in adhering to health protocols or allowing people to work for food.

The case of ambiguity in an interesting area to be discussed occurred in East Java, namely the cross dispute between the Governor of East Java and the Mayor of Surabaya regarding the surge in positive cases of Covid-19 in Surabaya and efforts to overcome them. The Surabaya government seeks to limit vehicles entering from outside however, the Governor's response was to the contrary, hoping for coordination with the provinces regarding the restrictions on these vehicles. A disagreement between these governments had reflected in several cases such as the PT HM Sampoerna cigarette factory were reported dozen new positive cases. Parallelly the curve of positive corona cases has increased significantly in Surabaya making the area a black zone.

\section{Social Transformation}

There are new habits for human being after Covid-19 spreading out entire the world. It means that human being is change their habits and attitude and in social science called as social transformation. (Castle, 2003; Maton, 2000) The social structure affects the environment and vice versa. Giuseppe Feola (2015) stated that changes in society lead to changes in the environment as is suspected to be the cause of the emergence of Corona Virus in China. Changes that occur in the environment will bring changes back to society. As Cass (2018) Infrastructures-road, rail, electricity, gas, water, broadband-are typically conceptualized as 'large', extensive, and somewhat durable systems which are interdependence with societal transformation. Global environment change has a big deal for creates social transformation changing social structure. change brings the societal transformation. Social network contributes to the social adaptation and transformation (Barnes, 2017) Regarding the pandemic disease, at least in the short research, there is an increasing worries of society mind causing the pandemic situation in the third week of September 2020 as below figure 5 .

Furthermore, Feola (2015) argued that "society finally need to adapt ... with the most important thing being the adjustment of institutional aspects so that transformation can run smoothly". This opinion does not seem to fit the pandemic conditions in Indonesia. The current era of VUCA causes institutions, elite figures and the public appear to still not be aligned towards social transformation as it is believed to be a solution to peaceful living following health protocols and the spread of COVID-19 can be suppressed / there has been no increase. However, the expectations of many parties as conveyed by the President in May are still far from expectations. The trend of increasing Covid-19 cases continues to increase and does not decrease as has happened in other countries.

After seven months of the pandemic spreading in Indonesia, community is getting bored, the apparatus is getting tired (Tempo.co.id, Selasa, 13 Oktober 2020 17:22 WIB; Kompas TV Selasa, 13 Oktober 2020 17:22 WIB; Liputan 6, 03 Des 2020, 10:00 WIB), the economic burden is getting more difficult for the people so that compliance with health protocols begins to loosen. Even, Worley (2020) argued that oversized impact of the Corona Virus pandemic on communities of color suggests that too much of our leadership, organization design, and change research has slanted discussions away from uncomfortable realities. In fact, Worley (2020) argues that the biggest impact of the Corona Virus pandemic is too much leadership, complicated organization, thus distracting the discussion from uncomfortable realities. It is happened in Indonesia, public concern about this disease break became fade and so there has been an explosion in the number of people who have contracted the plague to more than 1000 cases almost every day since midJanuary 2021. On the other hand, it was clear that the government was hesitant and nervous about the fact that this disease outbreak made various policies ineffective.

\begin{tabular}{|c|c|c|}
\hline & $(1=$ very disagree $)$ & ( $7=$ very agree $)$ \\
\hline At current & 5.73 & \\
\hline 3-4 months ago & 5.68 & \\
\hline 5-6 months ago & 5.46 & \\
\hline
\end{tabular}

Figure 5: Worry to be infected by Covid-19 $(n=969)$ 


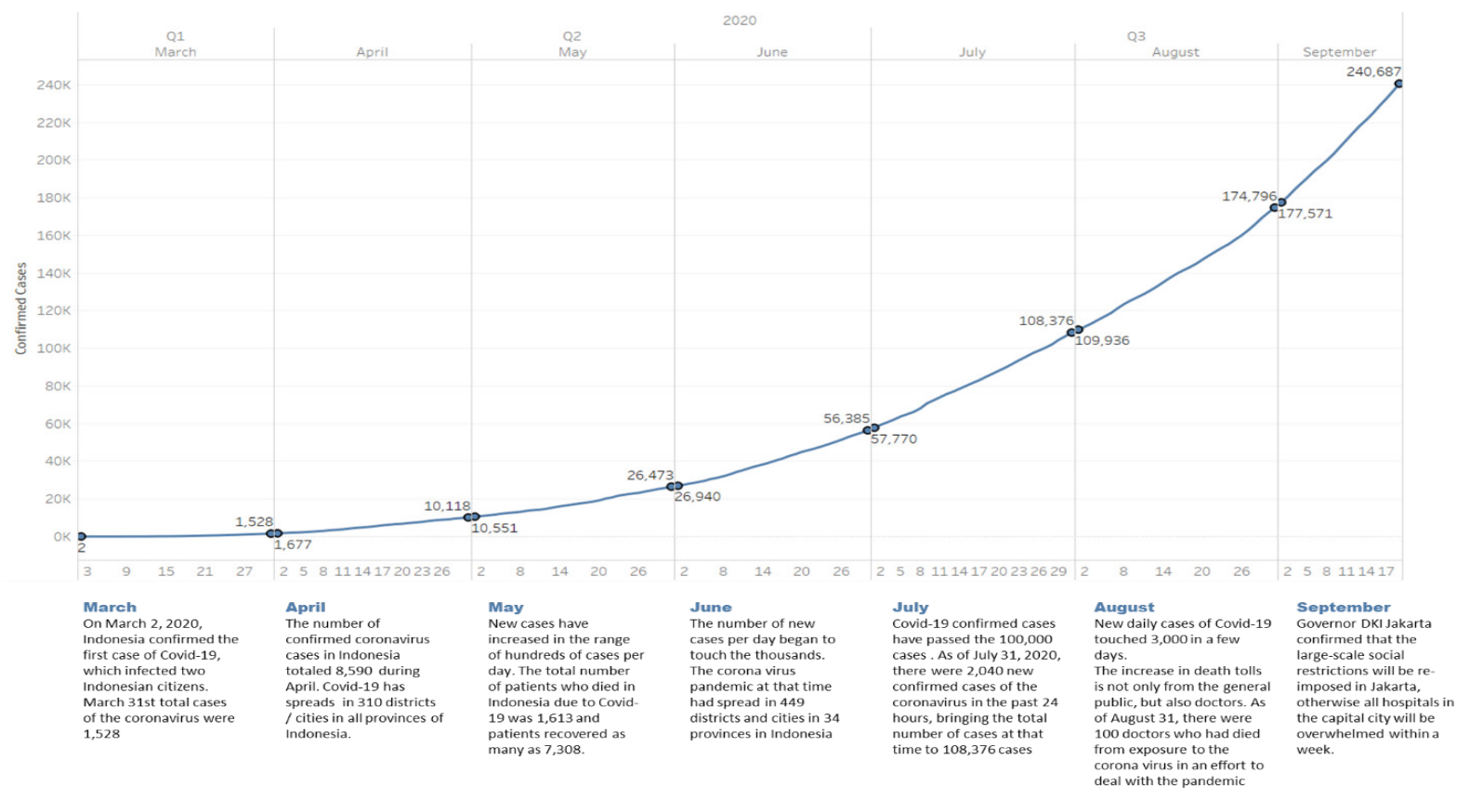

Source: collected from many sources

Figure 6: The First Seven Months of Outbreak

\section{CONCLUSION}

Pandemic Covid-19 in Indonesia has jumped to the VUCA consequences that build the situations getting more volatile, uncertainty, complex and ambiguity. There are no easy choices of public policy to guide the people in social transformation to be care about health protocol. De Roo (2017) mentions it as the "world of becoming", which is a form of environmental change caused by the high complexity in society. The social environment is not conducive to facilitate people living in the new normal. The suggestion of Nathan Bennett, \& G. James Lemoine (2014) to increase agility, to manage a huge and good information, institutional restructuring and develop some experiments could not be implemented in this pandemic season. The complexity that occurs does not provide a guarantee that social transformation concerned with health protocols will become new habits as mentioned in the new normal concept. It is also the recommendation of Aura Codreanu (2016) cannot be applied well. There were some less of social solidities from people and government officers facing Covid-19. They mean that real challenges to transform society to live in peace without worry about the threat of Corona Virus. However, optimism began to emerge when the vaccine became available in the second week of January 2021, albeit in very limited quantities and with no guaranteed hundred percent effectiveness. Moreover, we believe that social concern, togetherness, and responsibility are the clues to arrive a new normal. Further study is needed to synthesize any difficulties to create a better solution and develop a sharpen theoretical framework.

\section{REFERENCES}

Ariadne, E., Dewi, S. \& Sumartias, S. (2017). Promosi Kesehatan HIV-AIDS dan Stigma Terhadap Pengguna Narkoba Suntik (PENASUN) di Kabupaten Sumedang. Sosiohumaniora, 19(2), 129-140: https://oi.org/10.24198/ sosiohumaniora.v19i2.11403.

Azis, A., Komalasari, K., \& Masyitoh, I.S. (2020) Strenghtening young Generation characters in the disruption era through the internalization of Wayang Golek values. SosioHumaniora 3(22). 356-364 https://doi.org/10.24198/ sosiohumaniora.v22i3.26162.

Antara, "Pandemi COVID-19 Bikin Orang Jenuh, Namun Tetaplah Waspada" Tempo.com. diakses 13 Oktober 2020 17:22 WIB. pada https://gaya.tempo.co/read/1395628/ pandemi-covid-19-bikin-orang-jenuhnamun-tetaplah-waspada.

Barnes, M. L., Bodin, Öjan, Guerrero, Angela M., McAllister, Ryan, R. J., Alexander, Steven M., Robins, \& Garry (2017). The social structural foundations of adaptation and transformation in social \& ecological systems. Ecology and Society, 22(4), art16-. http://doi:10.5751/ES09769-220416. 
Bennett, N., James, L.G. (2014). What a difference a word makes: Understanding threats to performance in a VUCA world. Business Horizons, 57(3), 311-317. http:// doi:10.1016/j.bushor.2014.01.001.

Boullier, D. (2017) Big Data Challenge for Social Sciences: From Society and Opinion to Replications, ISA Symposium of Sociology. https://esymposium.isaportal.org/resources/ resource/big-data-challenge-for-socialscience/download/.

Casey, G.W. (2018). Leading in a Vuca World . Johnson Cornell St George College Business.

Cass, N., Schwanen, T., \& Shove, E., (2018) Infrastructures, Intersections and Societal Transformations in Technological Forecasting \& Social Change 137 (2018) 160-167. https:// doi.org/10.1016/j.techfore.2018.07.039.

Castells, M. (2010) The Rise of the Network Society, Second edition. UK: Wiley \& Blackwel.

Castle, S. (2003). Towards a Sociology of Forced Migration and Social Transformation. BSA Publications Ltd $\AA$. 37(1), 13-34 [00380385(200302)37:1;13-32;030384] SAGE Publications London,Thousand Oaks, doi: 10.1177/0038038503037001384. http://soc. sagepub.com/content/37/1/13.

Codreanu, A. (2016). A Vuca Action Framework For A Vuca Environment. Leadership Challenges And Solutions. Journal of Defense Resources Management, 7(2), 31-38. Retrieved from https://www. proquest.com/scholarly-journals/vucaaction-framework-environment-leadership/ docview/1851703435/se-2.

Dwivedi, Y.K., Kelly, Gerald, Janssen, Marijn, Rana, Nripendra P., Slade, Emma L., Clement, \& Marc (2018). Social Media: The Good, the $\mathrm{Bad}$, and the Ugly. Information Systems Frontiers. 20, 419-423 doi:10.1007/s10796018-9848-5.

Devira Prastiwi, "Tembus 8.000 Orang, Jumlah Pasien Covid-19 Jadi 557.877 Kamis 3 Desember 2020", Liputan6.com. diakses 03 Des 2020, 16:20 WIB pada https://www. liputan6.com/news/read/4424402/tembus8000-orang-jumlah-pasien-covid-19-jadi557877-kamis-3-desember-2020.

Dian Erika Nugraheny, "UPDATE 10 Agustus: Bertambah 1.284, Kini Ada 82.236
Pasien Sembuh dari Covid-19”, Kompas. com. Diakses 10 Agustus 2020, 06:54 WIB pada https://nasional.kompas.com/ $\mathrm{read} / 2020 / 08 / 10 / 15294691 /$ update-10agustus-bertambah-1284-kini-ada-82236pasien-sembuh-dari-covid-19. .

Dian Erika Nugraheny, "UPDATE 13 Oktober: Ada 65.299 Kasus Aktif Covid-19 di Indonesia", Kompas.com. Diakses 13 Oktober 2020, 17:22 WIB pada https://nasional.kompas.com/ $\mathrm{read} / 2020 / 10 / 13 / 16080591 /$ update-13-oktoberada-65299-kasus-aktif-covid-19-di-indonesia.

Fahmi, M., Panjaitan, N.A., Habibie, I., Siregar, A. Y. M., Amarullah, G., Rahma \& Sunjaya, D. K. (2019) Does your neighborhood protect you from being depressed? A study on social trust and depression in Indonesia. BMC Public Health. https://doi.org/10.1186/s12889-0197657-5.

Feola, G. (2015). Societal transformation in response to global environmental change: A review of emerging concepts. Ambio, 44(5), 376390. http://dx.doi.org/10.1007/s13280-0140582-z.

Fukuyama, F. (1999), The Great Disruption: Human Nature and the Reconstitution of Social Order, USA: The Free Press.

Giraud, T., \& Shiller, R.J. (2021). Narrative Economics: How Stories Go Viral and Drive Major Economic Events". Book Review on Journal of the History of Economic Though., 1-6. doi:10.1017/S1053837221000110.

González-Sanguinoa, C., Ausína, B., Castellanosb M. Á., Saizc, J., López-Gómezd, A., Ugidosc, \& C. Munoz, M., (2020). Mental health consequences during the initial stage of the 2020 Coronavirus pandemic (COVID-19) in Spain, in Brain, Behavior, and Immunity, 87 (2020) 172 -176. https://doi. 10.1016/j. bbi.2020.05.040.

Maton, K. I. (2000). Making a difference: The social ecology of social transformation. American Journal of Community Psychology, 28(1), 25-57. doi:http://dx.doi. org/10.1023/A:1005190312887.

Ohmae, K. (1995). The end of the Nation States and the Rise of Regional Economies. USA: The Free Press.

Umeozor, S. N. (2019). Information networking and its application in the digital era with illustration 
from the University of Port Harcourt Library. International Journal of Knowledge Content Development \& Technology, 9(2), 33-44.

Tulder, R.V., Jankowska, B. and Verbeke, A. (2019), «Introduction: Progress in International Business Research in an Increasingly VUCA World», Tulder, R.V., Verbeke, A. \& Jankowska, B. (Ed.) International Businessina VUCA World: The Changing Role of States and Firms (Progress in International Business Research, 14, 1-20. Emerald Publishing Limited, Bingley, https://doi. org/10.1108/S1745-886220190000014001

Worley, C. G. and Jules, C, (2020), COVID-19's Uncomfortable Revelations About Agile and Sustainable Organizations in a VUCA World. The Journal of Applied Behavioral Science 1-5. doi: 10.1177/0021886320936263. 